\title{
ポリェステル系熱可塑性エラストマーの 反応押出に上る改質
}

倉持智宏* ・稲葉智一 ${ }^{*}$, 大村洋司* - 伊保内賢*

\section{Modification of Thermoplastic Polyester-Polyether Elastomer by Reactive Extrusion}

\author{
Tomohiro Kuramochi*, Tomokazu Inaba*, Youji Omura* \\ Masaru IBOnAi*
}

\begin{abstract}
A thermoplastic elastomer (TPE) is an elastomer at room temperatures which can be molded at high temperatures like normal thermoplastics. However the compression set of a TPE is higher than that of crosslinked rubbers. In this study, we tried crosslinking a thermoplastic polyester-polyether elastomer (TPEE) with triglycidyl or tetraglycidyl compounds during extrusion to reduce the high compression set. Crosslinked TPEE could be obtained easily in a single screw extruder. The tensile strength and tensile impact strength of the molded TPEE were found to be higher than those of the original TPEE respectively. The compression set of TPEE was improved by its reactive extrusion with glycidyl compounds.

Key words : Polyester-polyether elastomer/Glycidyl compound/Reactive extrusion/ Crosslinking reaction/Compression set
\end{abstract}

\section{1. 緒言}

熱可塑性エラストマー (TPE) は, ハードセグメン トとソフトセグメントからなるブロックコポリマーで あり, ハードセグメントが凝集し，ドメインを形成す ることにより，加硫ゴムの架橋点である硫黄のような 役割をしている1),2). しかし，通常使用されている架 橋ゴムに比べ, TPE は従来の熱可塑性プラスチック の成形機をとのまま用いて迅速に加工ができる反面, 弾性率が小さく，圧縮永久ひずみが大きいという久点 がある。しかし，TPE が他のプラスチックとブレン ドできるといら利点を生かしてェンジニアリングプ

* 工学院大学 工学部 応用化学科

八王子市中野町 2665-1 (宁 192)

Department of Applied Chemistry

Kogakuin University

2665-1 Nakano-machi, Hachioịi, Tokyo 192 Japan 1996. 2.7 受理
ラスチックとのアロイの研究も行われており, 例光 ば，最近ではナイロンにポリアミド系ェラストマー (TPAE) を添加して耐衝撃性の改善を検討している 報告 ${ }^{3) ~ 5)}$ がある.

著者らは以前に, リアクティブプロセッシングの適 用として, ナイロン 11 とナイロン $12^{6)}$, ポリエチレ ソテレフタラート $(\mathrm{PET})^{7), 8)}$, ポリアミド $(\mathrm{PA})$ とポ リエステル ${ }^{9)}$ の改質を行い, 機械的性質, 耐熱性, 耐 薬品性および吸水性を改善することができた、最近で は，TPAEを多官能グリシジル基を有した橋かけ剤を 用いて，反応押出により，部分橋かけを行い，圧縮永 久ひずみの小さな橋かけ物を得た10),11).

本研究では，ポリエステル系 TPE (TPEE) に，前 報 ${ }^{10)}$ と同様な手法を用いて，適度な橋かけを行うこと で，熱可塑性を維持させたまま TPEE の欠点である 圧縮永久ひずみの改善を試みた12). 


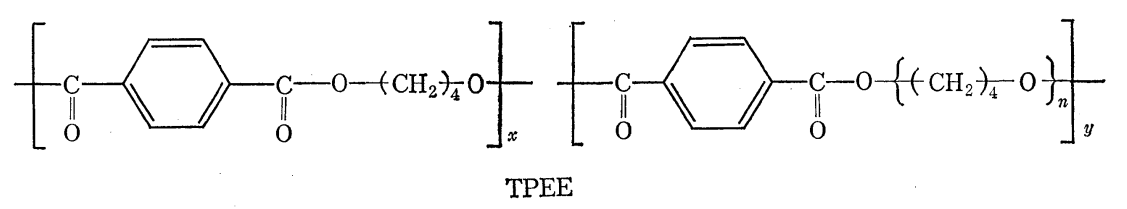

Fig. 1

Structures of TPEE and crosslinking agents<smiles>O=c1n(CC2CO2)c(=O)n(CC2CO2)c(=O)n1CC1CO1</smiles>

TGI

\section{2. 実験}

\section{1 試料}

TPEE は東洋紡績製の「ペルプレン P-70 B」をそ のまま使用した、橋かけ刻として三菱ガス化学製の三 官能エポキシ化合物イソシアヌル酸トリグリシジル (TGI)，チバガイギー社製の四官能エポキシ化合物 テトラグリシジル $-4,4^{\prime}-$ ジアミノジフェニルメタン （TGDDM）を使用した．Fig. 1 にこれらの構造式を 示す.アルカリ触媒として和光純薬工業製無水炭酸カ リウム一級品を使用した。

\section{2 押出試料の作成}

TPEE を真空乾燥機中 $70^{\circ} \mathrm{C}, 5$ 時間乾燥し, 橋か

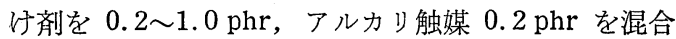
した後，大栄エンジニアリング製 EX-3024 AUF 型 単軸スクリュ押出機 (スクリュ径 $30 \mathrm{~mm}$, スクリュ $L / D 24)$ によってフィルム状押出成形物を作成した. 設定温度は，ホッパー側から 195-205-200-175-175ㄷ スクリュ回転数は $10 \mathrm{rpm}$ とした。また，押出成形時 に滞留時間，樹脂圧力を測定し，橋かけ䨩あるいは添
加量などによる変化を調べた。

\section{3 機械的強度}

\section{a . 引張強さ測定}

押出成形によって作成されたフィルム状押出成形物 を中心部の幅が $5 \mathrm{~mm}$ のダンベル型 (Fig. 2) に打ち 拔き，真空乾燥機にて $70^{\circ} \mathrm{C} ， 5$ 時間乾燥した。 サン プルの厚さは中心部の厚さをマイクロメーターによっ て3 個所測定し，その平均を用いた．引張試験は島津 製作所製オートグラフ S 100 型を用い，引張速度 5 $\mathrm{cm} / \mathrm{min}$, 温度 $23^{\circ} \mathrm{C}$ にて測定した。 引張強さは少な くとも 5 サンプルの測定值の平均をとった。また，サ ンプルが切断されるまでの伸び率（\%）る測定した.

\section{b ・ 引張衝擊強さ測定}

引張強さ測定と同様に, 押出成形物を Fig. 3 亿示し たようなダンベル型に打ち抜き，真空乾燥機にて 70 ${ }^{\circ} \mathrm{C}, 5$ 時間乾燥した。 サンプルの厚さとして中心部の 厚さをマイクロメーターによって測定し，東洋精機製 作所製の万能衝撃試験機を用いて, 温度 $23^{\circ} \mathrm{C}$ で測定 した．引張衝撃強さは少なくとも5 サンプルの測定值

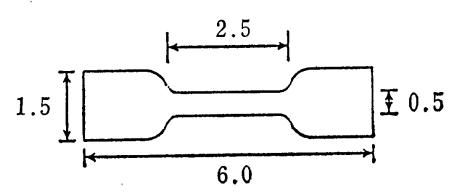

Fig. 2 A test piece for tensile strength (Unit : $\mathrm{cm}$ )

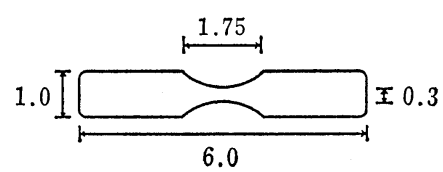

Fig. 3 A test piece for tensile impact strength (Unit : $\mathrm{cm}$ ) 


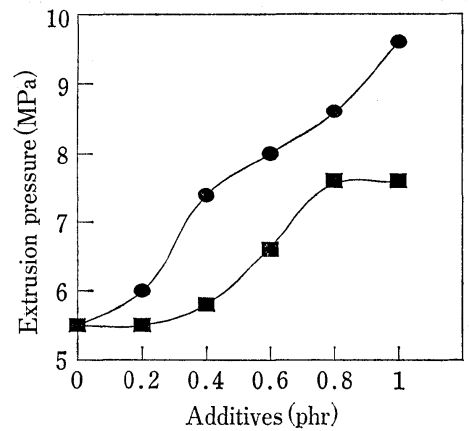

Fig. 4 Extrusion pressure of TPEE at the reactive extrusion with several additives (TGI, : TGDDM)

の平均とした。

\section{c. 硬度測定}

押出成形物を細かく刻み，金型に入れて加熱溶融し， $4.5 \mathrm{~cm} \times 1.5 \mathrm{~cm} \times 0.65 \mathrm{~cm}$ の直方体試験片を作成乙 た. ゴム硬度計用定圧荷重器 (CL-50 型) に取り付け られた硬度計（ショアD型，ともに高分子計器製）を 用いて，表面上を 7 点測定し，その平均を試験片の硬 度とした。

\section{4 粘 度 測 定}

押出成形物をクロロホルムに溶解して Ostward 粘 度計を用いて，粘度法により極限粘度 $[\eta]$ を $25^{\circ} \mathrm{C}$ で測定した。 また，前報 ${ }^{10)} の$ TPAE についても同様， 極限粘度 $[\eta] を 25^{\circ} \mathrm{C}$ で測定した。溶媒は $m$ ークレ ゾールを用いた。

\section{5 見掛けの圧縮永久ひずみ測定}

押出成形物を細かく刻み，金型に入れて加熱溶融後， 冷却し, $4.5 \mathrm{~cm} \times 1.5 \mathrm{~cm} \times 0.65 \mathrm{~cm}$ の直方体試験片 を得た．油圧プレスを用いて垂直に $1.5 \mathrm{MPa}$ の圧力 を 5 時間かけた後，圧力を除去し， 2 分ごとに 50 分 間厚さを測定し，ひずみ回復の様子を調べた。試験温 度は $23^{\circ} \mathrm{C}$, 圧力除去 $x$ 分後の試験片のひずみ率 $S_{x}$ （\%)を次式に上って求めた.

$$
S_{x}(\%)=\frac{T-T_{x}}{T} \times 100
$$

ここで, $T$ は圧縮前の試験片の厚さ $(\mathrm{mm}), T_{x}$ は圧 縮除去 $x$ 分後の試験片の厚さ $(\mathrm{mm})$ である.

\section{3. 結果と考察}

\section{1 成形時の滞留時間, 樹脂温度, 樹脂圧力}

TPEE に触媒のみを加えることにより，滞留時間， 樹脂温度に変化はなかったが, 溶融粘度の低下に伴う 樹脂圧力は拉よそ $14 \%$ 減少した。このことから，

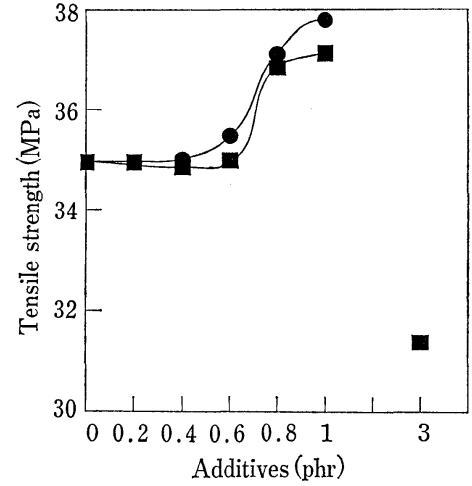

Fig. 5 Tensile strength of TPEE obtained after the reactive extrusion with several additives (Tensile speed : $50 \mathrm{~mm} /$ min, Measuring temperature : $23^{\circ} \mathrm{C}, \mathrm{T}: \mathrm{TGI}, \mathrm{TGDDM}$ )

TPEE は触媒によって分子鎖の切断が起こっているも のと推測できる.

TPEE に触媒, 橋かけ剂を添加した系においては, 橋か忷剤の添加量が増光るに従って, 滞留時間, 樹脂 圧力が上昇した．このときの樹脂圧力を Fig. 4 亿示す このことから，TPEE と橋かけ剤は押出機内で反応し ていることが推測された。なお，TPEE に TGDDM を $1.0 \mathrm{phr}$ より多く添加するとバレル内で固化, 脆く なりフィルム状にならなかった。

\section{2 機械的強度}

\section{a. 引張強さ}

引張強さは，低い橋か沙度に扮いて顕著に増大し， 橋かけが増すにつれて急速に低下することが知られて

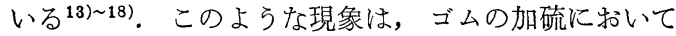
は橋かけによる網目構造の不均一性が引き起こすレザ 一領域の発現のためと考光られており ${ }^{19)}$, 本 TPEE でも同様な現象が起こっていると推測される. しかし， 熱可塑性エラストマーには物理架橋が存在し，この系 ではその一部が崩壊している可能性があるので，ゴム の加硫の場合とは異なる要因によっていることも考光 られる. Fig. 5 に橋かけ剤添加量に対する引張強さの 変化を示す，橋か梳剤を加光るに従って強度が上昇し， $1.0 \mathrm{phr}$ 添加付近で上昇幅が小さくなった。

一般的に，橋かけが進行すると破断伸び率は減少す $3^{14) \sim 18)}$. 引(張試験時に測った伸び率を Fig. 6 に示す. しかし，TPEEへの橋かけでは，橋かけ剤を加党るこ とにより，逆に伸び率が上昇した。本研究で用いた TPEE は，プラスチック的性質をむったエラストマー であり，橋かけを行らことによって結晶化度が低下し， 


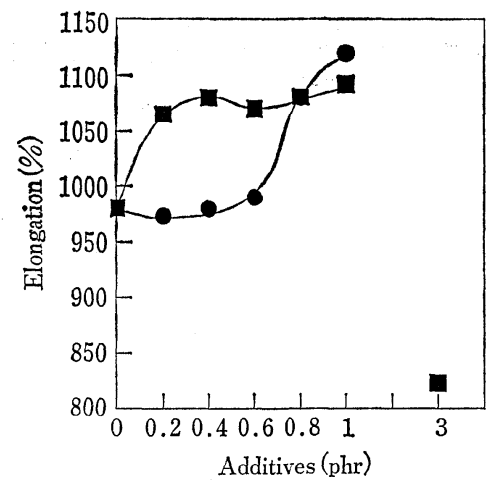

Fig. 6 Elongation of TPEE obtained after the reactive extrusion with several additives (Tensile speed : $50 \mathrm{~mm} / \mathrm{min}$, Measuring temperature : $23^{\circ} \mathrm{C}, \mathbf{0}:$ TGI, : TGDDM)

伸び率が上昇したと考兄られる。

理論計算により，規則正しい間隔の橋かけを持つ網 目は，橋かけの間隔がランダムである網目よりも大き い破断伸びを持つはずである。また， 3 官能性橋かけ 点を含む網目は，4官能性橋かけを含む網目より大き い破断伸びを持つはずである ${ }^{13)}$ 乙つかしながら，本 実験では橋かけ剂の添加量が微量であるために，完 全な網目構造をとっていないためか，TGI に比べて TGDDM がわずかに機械的強度が大きく，そのよう な傾向はみられなかった。

b. 引張衝撃強さ

Fig. 7 に橋か汗剂添加量に対する引張衝撃強さの変 化を示した。一般的に微量の橋かけ郕を添加すると， 橋かけによって引張強さは上昇するが，破断伸び率が

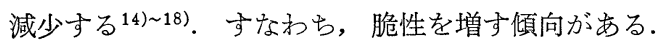
しかしながら, 今回の TPEE への橋かけでは引張衝 撃強さが上昇した。これは橋かけ剂による分子量の 増大, また, 結晶化度の低下によるものと考光られ

Table 1 Shore hardness (type D) of TPEE obtained after the reactive extrusion with several additives

\begin{tabular}{l|c}
\hline \multicolumn{1}{c|}{ Sample $^{\text {a) }}$} & Shore D \\
\hline TPEE only & 30 \\
TPEE + TGI 1.0 phr & 41 \\
TPEE+TGDDM 1.0 phr & 44 \\
\hline
\end{tabular}

a) Loaded with $0.2 \mathrm{phr} \mathrm{K}_{2} \mathrm{CO}_{3}$ as catalyst except TPEE alone

ASTM D 2240

Measuring temperature $: 23^{\circ} \mathrm{C}$

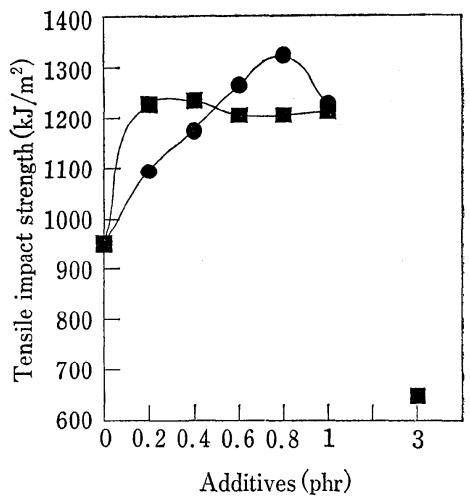

Fig. 7 Tensile impact strength of TPEE obtained after the reactive extrusion with several additives (Measuring temperature : $23^{\circ} \mathrm{C}$ : TGI, TGDDM)

$ろ^{13), 14)}$ 引引張強さ測定の結果と併せて考光ると，橋 かけ剤を加えることによって引張強さが上昇し，なお かつ衝撃強さも上昇することから, 剛性, じん性とも に優れた新規 TPE を作成できたと考えられる。

\section{c. 硬度}

引張強さの項でも述べたように，橋かけ郕を加える ことによってゴム硬度が上昇した（Table 1)，前報 ${ }^{10)}$ の PA 系 TPEを用いた橋かけ反応では大きく変化し なかったが，TPEE の硬度は 30 から TGI 添加で 41, TGDDM 添加で 44 とかなり硬くなった.

\section{3 極限粘度変化}

分子量は極限粘度 $[\eta]$ から経験的に求めることが できるが，TPEE の経験值が明らかにされていないた め, 極限粘度の比較によって橋加剂添加による分子 量増加の確認とした (Table 2). 結果は予想通り橋か

Table 2 Intrinsic viscosity of TPAE and TPEE obtained after the reactive extrusion with several additives

\begin{tabular}{l|l}
\hline \multicolumn{1}{c|}{ Sample } & {$[\eta]$} \\
\hline TPAE only ${ }^{\mathrm{a}}$ & 1.1 \\
TPAE+TGI $1.0 \mathrm{phr}^{\mathrm{a})}$ & 2.0 \\
\hline TPEE only & 0.94 \\
TPEE $+\mathrm{K}_{2} \mathrm{CO}_{3} \quad 0.2 \mathrm{phr}^{\mathrm{b})}$ & 0.91 \\
TPEE + TGI $1.0 \mathrm{phr}^{\mathrm{b})}$ & 1.18 \\
TPEE+TGDDM $1.0 \mathrm{phr}^{\mathrm{b})}$ & 1.30 \\
\hline
\end{tabular}

Solvent a ) : $m$-cresol b) : chloroform

Measuring temperaure $: 25^{\circ} \mathrm{C}$ 


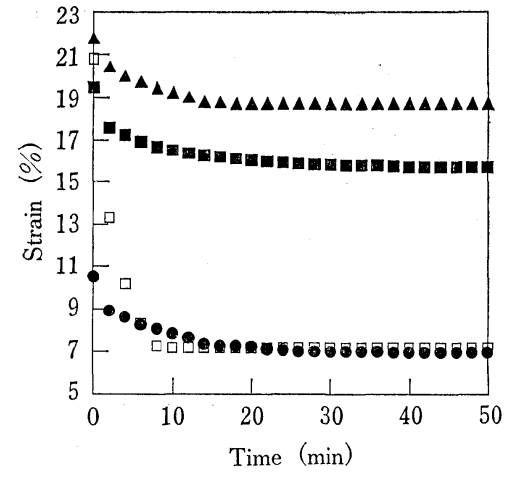

Fig. ${ }^{\circ} 8$ Strain recovery of TPEE obtained after the reactive extrusion with several additives (Measuring Temperature : $23^{\circ} \mathrm{C}, \mathrm{TGI}$, TGDDM, : TPEE, $\square: 1,2-$ polybutadiene)

けすることにより， [ク]苂上昇した，前報の PA 系

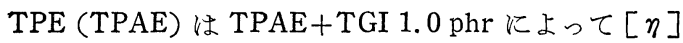
が 1.1 から 2.0 となり, 本 TPEE では, TPEE+

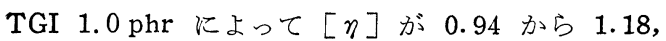

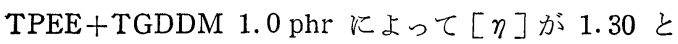
なった。

分子量と直接関係ある極限粘度 $[\eta]$ が増加するこ とから, TPEE と橋かけ剂とは橋かけ反応あるいは鎖 伸長反応していることが裏付けられた。な和，TPEE は添加量 $1.0 \mathrm{phr}$ までのものはクロロホルムに溶解し たが，3.0 phr 添加したものは不溶となった。

また, TPEE にアルカリ触媒を加光た時の［ク］は， 0.94 から 0.91 と減少して搞り, アルカリ触媒によっ て TPEE の分子鎖が切断されることが裏付汀られた.

\section{4 見掛けの圧縮永久ひずみ}

Fig. 8 飞各種橋かけ剤 $1.0 \mathrm{phr}$ を添加した場合の押 出成形物の圧縮除去後のひずみ回復の経時変化を示す. 橋かけ剤として TGDDM を添加したものは, 見掛け

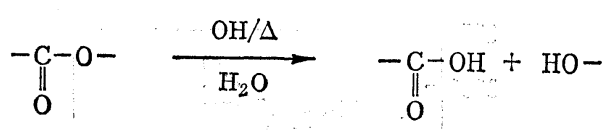

\section{Scheme 1}

の圧縮永久ひずみが特に改善され，架橋 1,2 -ポリブ タジェンと泳同じになった。

ここで，硬度測定の結果と照らし合わせてみると， TPEE に橋かけ剤を加光るときの硬度の増加が著しい つまり，TGDDM 添加での圧縮永久ひずみの減少は， 試料が橋かけによって硬化したため, 圧縮してもひず まなかったためである、ひずみの回復率を荷重時の試 料に対して計算したところ，TPEE のみでは 3.06\% 回復したのに対して, TGI $1.0 \mathrm{phr}$ 添加では $3.58 \%$, TGDDM $1.0 \mathrm{phr}$ 添加では $3.53 \%$ 回復した. さらに 添加量を変えて検討したところ, TGDDM $0.2 \mathrm{phr}$ 添 加で $11.50 \%$ の回復率を示した.

\section{4. 反応機 構}

押出成形機内での反応は，まず TPEE の分子鎖が 触媒と熱によって切断され，末端基を生成 (Scheme 1), 次に TPEE のカルボキシル基, 水酸基とェポキ シ化合物のグリシジル基とが反応し201 22), 橋かけが 導入されると考光られる (Scheme 2). その他に， TPEE の末端基にエポキシ基が反応する鎖伸長反応も 考えられる。また，酸やアルカリの存在下で熱を掛け ると，末端のカルボキシル基と鎖中のエステル結合が エステル交換を起こすことが考兄られる (Scheme 3) が，高分子鎖同士の反応上りは高分子と低分子との反 応速度が大きいと考光られ，このエステル交換反応の 影響は小さいであるう。

\section{5. 結 言}

TPEE に少量の橋かけ剤とアルカリ触媒を添加し， 反応押出することにより，TPAE 同様，押出機中で部 分橋かけあるいは鎖伸長反応が起こり, 熱可塑性を維

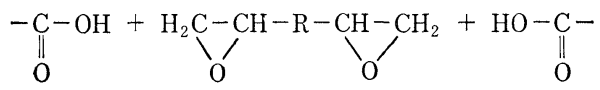

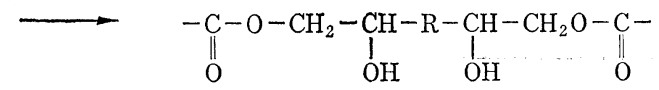$$
-\mathrm{OH}+\bigvee_{0}^{\mathrm{H}_{2} \mathrm{C}-\mathrm{CH}}-\mathrm{R}-\mathrm{C}_{\mathrm{O}}^{\mathrm{CH}}-\mathrm{CH}_{2}+\mathrm{HO}-
$$$$
\longrightarrow \begin{gathered}
-\mathrm{O}-\mathrm{CH}_{2}-\underset{\mathrm{O}}{\mathrm{CH}}-\mathrm{R}-\mathrm{CH}-\mathrm{CH}_{2} \mathrm{O}- \\
\mathrm{OH} \quad \mathrm{OH}
\end{gathered}
$$

Scheme 2 


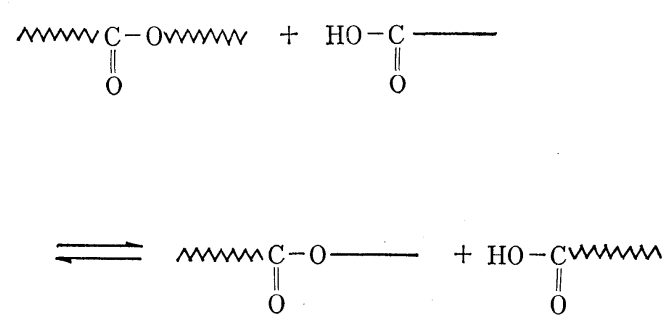

Scheme 3

持したまま容易に圧縮永久ひずみの小さな成形物を得 ることができた，さらに分子量の増大招よび機械的強 度の向上は様々な分野への用途拡大が期待される.

\section{参考 文 献}

1) 内山 晃: プラスチックス, 44(1), 145 (1993)

2）塚原安久，麴谷信三：プラスチックス，42(10), 18 (1991)

3）詹 茂盛, 栗山 卓, 成澤郁夫, 藤本元弘 : 高分 子論文集, 52(5)，272（1995）

4）詹 茂盛, 栗山 卓, 成澤郁夫, 藤本元弘 : 高分 子論文集，52(8)，48（1995）

5）詹 茂盛, 栗山 卓, 成澤郁夫, 藤本元弘 : 成形 加工, 7(10), 653 (1995)

6) 伊野卓幸, 粕谷裕司, 菊池武彦, 倉持智宏, 寺町 信哉, 伊保内賢：成形加工，3(9)，624（1991）

7) 粕谷祐司, 渡辺康史, 菊池武彦, 倉持智宏, 寺町
信哉，伊保内賢：成形加工，5(3)，205（1993）

8）青木良幸, 金城将人, 倉持智宏, 橋本和彦, 伊保 内賢：成形加工，6(11)，811 (1994)

9）渡辺康史, 稲葉智一, 菊池武彦, 倉持智宏, 伊保 内賢：成形加工，6(2)，125（1994）

10）倉持智宏, 稲葉智一, 夏目隆行, 青木良幸, 伊保 内賢：日本ゴム協会誌，68(1)，54（1995）

11）伊保内賢, 倉持智宏, 稲葉智一: 特開平 7-138367

12）伊保内賢, 倉持智宏, 稲葉智一: 特開平 7-138355

13） Nielsen, L.E.: 高分子と複合材料の力学的性質, pp. 169 170，（1976）化学同人

14) Flory, P. J., Rabjohn, N. and Shaffer, M.C.: J. Polym. Sci., 4, 435 (1949)

15) Taylor, G. R. and Darin, S. R.: J. Polym. Sci., 17, 511 (1955)

16) Smith, T. L. and Magnusson, A. B.: J. Polym. Sci., 42, 391 (1960)

17) Hill, F. B., Young, C.A., Nelson, J.A. and Arnold, R. G.: Ind. Eng. Chem., 48, 927 (1956)

18) Dubeh, T. J. and Buecke, F.: J. Appl. Polym. Sci., 8, 555 (1964)

19）中内秀雄, 内藤壽夫, 井上 栄：日本ゴム協会誌, 66(2), 117 (1993)

20) Gorton, B. S.: J. Appl. Polym. Sci., 8, 1287 (1964)

21）橋本邦之：エポキシ樹脂（プラスチック材料講座 1 )，55，(1962）日刊工業新聞社

22) 大河原信：高分子の化学反応 10 (上巻)，124, (1972) 化学同人 